Original article

\title{
Docking Studies on the Effects of Some Bioactive Compounds from Pistacia atlantica Desf. against Main Protease SARS-CoV2
}

\author{
Taıb Nadjat (i) a,b, ", Sıtayeb Tayeb (i) b ${ }^{\text {, }}$ Necmi Beşer (i) c \& Aıssaouı Nadia (1) d \\ a Department of Biology, Laboratory of Hydric Resources and Environment, University of Saida, Algeria \\ ${ }^{b}$ Department of Biology, Laboratory of Biotexicology, Pharmacognosy and Valorization of Plants, University of Saida, Algeria \\ 'Departement of Genetics and Bioengineering, Faculty of Engineering, Trakya University, Edirne, Turkey \\ ${ }^{d}$ Department of Biology, Faculty of Nature Sciences and Life, University of Abou Bekr Belkaid Tlemcen, Algeria
}

\begin{abstract}
Novel coronavirus which was named later as SARS-CoV2 appeared in Wuhan, China, in the end of December 2019. Actually, no precise drugs are existed and research concerning SARS-CoV2 treatment is deficient. SARS-CoV2 main protease (Mpro) was crystallized by Liu et al. (2020) and represented a crucial drug target. The present work aimed to evaluate some bioactive compounds from Pistacia atlantica as possible SARS-CoV2 Mpro inhibitors, based on molecular docking approach. Molecular docking was carried out using AutoDock Vina software. The results indicated that Beta-Eudesmol, Elemol, Verbenol, Pinocarvone, Myrtenal, Myrtenol and Trans-Carveol have a potential inhibitor activity of SARS-CoV2 Mpro. Nevertheless, further investigations are required to develop and optimize drug process to combat SARS-CoV2.
\end{abstract}

Keywords: SARS-CoV2, molecular docking, bioactive compounds, Pistacia atlantica.

Received: 25 June 2021 * Accepted: 29 September 2021 * Dol: https://doi.org/10.29329/ijiaar.2021.378.2

\footnotetext{
* Corresponding author:

Taıb Nadjat, Department of Biology, Laboratory of Hydric Resources and Environment, University of Saida, Algeria. Email: nano_Taib@hotmail.fr
} 
Nadjat et al. / Uluslararası Tarım Araştırmalarında Yenilikçi Yaklaşımlar Dergisi /

International Journal of Innovative Approaches in Agricultural Research, 2021, Vol. 5 (3), 269-278

\section{INTRODUCTION}

The genus Pistacia belongs to the Anacardiaceae family, it has a remarkable ecological amplitude and plasticity. Previous studies qualify $P$. atlantica Desf. as a precious species, due to its several therapeutic properties and attracts the attention in medical and pharmaceutical eras (Daget and Godron, 1974; Monjauze, 1980; Benhassaini, 2003; El Oualidi et al., 2004). In addition, this specie contains several secondary compounds including flavonoids, floroglucides, coumarins, tannins, anthracene derivatives, sugars, saponins, phenolic and alcaloids carbohydrates. Therefore, these compounds have antipyretic, antidiabetic, antiradical, cytotoxic activities (Hamdan and Afifi, 2004; Topçu et al., 2007; Benhammou et al., 2007, Benhammou et al., 2008), antioxidants, antimicrobial and anti-inflammatory (Farhoosh, 2008).

Until now, very few studies have investigated the antiviral potency of $P$. atlantica Desf., whereas, the antiviral properties of other Pistacia have been evaluated (Karimi et al., 2019). In the actual context, novel Coronavirus SARS-CoV-2 appeared in China at the end of December 2019 (Xu et al., 2020). Coronaviruses are RNA viruses that have huge viral RNA genomes (Chen and Liu, 2020). They encoded genes for an RNA polymerase, spike protein with trimeric structural (Xue et al., 2008; Chen et al., 2020), Membrane protein (M), Nucleocapsid protein (N), Envelop protein (E) and some nonstructural proteins (Boopathi et al.,2020). The main protease (Mpro) plays an important role in polyprotein and virus maturation. According to the three-dimensional structure of SARS-CoV-2Mpro made by Jin and al. (2020), SARS-CoV-2Mpro was composed with three regions in which the second region is the important binding of the inhibitors (Yang et al., 2003; Zhao et al., 2008). SARS-CoV-2Mpro is an attractive target for designing a therapeutic approach (Anand et al., 2003; Yang et al., 2003; Pillaiyar et al., 2016).

The characteristic of this novel virus is its rapid extension and cause a world pandemic. In this situation, finding a novel drug seems to be very urgent. Molecular docking is one of the promising tools which were employed for screening and developing a new drug. Also, this approach helps therapists how to administrate the drug in first instance (Liu et al., 2005). This tool is based on the study of the interaction established between drug (ligand) and target protein (receptor) (Mcconkey et al.,1983).

In this study, we selected Terpenoids compounds of $P$. atlantica Desf. as inhibitors against SARSCoV-2Mpro using docking molecular approach.

\section{MATERIAL and METHODS}

\section{Data set}

The leaves of P. atlantica Desf contain 49 identified compounds. According to Ait Said et al. (2011) these compounds were regrouped into: monoterpenes ( 8 hydrocarbons and 14 oxygenated) and sesquiterpenes (16 hydrocarbons and 9 oxygenated). In this study, we selected twenty terpenoids components based on conducted the docking study. 
Nadjat et al. / Uluslararası Tarım Araştırmalarında Yenilikçi Yaklaşımlar Dergisi /

\section{Docking protocol}

Docking calculations need a receptor and ligand representations in a file format called pdbqt which is a modified protein data bank (Berman et al., 2000). The format contains atomic charges, atom type definitions and, for ligands, topological information (rotatable bonds). These files preparations are carried out using Autodock 1.5.4 MGL Tools (Sanner, M. F., 1999). Ligands for subsequent docking runs can be prepared one by one through PyMol (DeLano, 2002) and Autodock 1.5.4 MGL Tools. The bioactive conformations were simulated using AutodockVina (Trott and Olsan, 2010). AutodockVina is a program for molecular docking and virtual screening for drug. It is used in many studies (Trott and Olsan, 2010; Sandeep et al., 2011; Jaghoori et al., 2016).The crystal structure of SARS-CoV-2main protease(PDB entry code: 6lu7) obtained from the protein database (http://www.rcsb.org) with original ligand and water were eliminated.

The best conformations of the ligands were analyzed for their binding interactions and were evaluated by the binding free energies (Docking affinity, $\mathrm{kcal} / \mathrm{mol}$ ) and bonds interactions between ligand atom and active site residues. Subsequently, the results were analyzed using PyMol and LigPlot+ (Laskowski and Swindells, 2011).

\section{RESULTS}

The results are presented in Table 1 and Table 2 demonstrated seven compounds generating the highest binding energy with SARS-CoV-2 main protease: Beta-Eudesmol $(-5.5 \mathrm{kcal} / \mathrm{mol})$ forming a hydrogen bond with the main protease at (Ser158, Lys102, Asp153), Elemol (-5.2kcal/mol) constituting a hydrogen bond at Ser 158, Verbenol (- 5.2kcal $/ \mathrm{mol})$ forming hydrogen bond at Thr111, Pinocarvone $(-5.1 \mathrm{kcal} / \mathrm{mol})$ and creating a hydrogen bond at Trp207. Myrtenal $(-4.9 \mathrm{kcal} / \mathrm{mol})$ at Thr292, Myrtenol (-4.9 kcal/mol) creating a hydrogen bond at Asn151, Thr111, finally Trans-Carveol (- $4.9 \mathrm{kcal} / \mathrm{mol})$ forming a hydrogen bond with the main protease at Lys (Figure 2). 
Table 1. The properties of terpenoids from the Pistacia atlantica leaf.

\begin{tabular}{|c|c|c|c|c|c|}
\hline Ligand & $\begin{array}{l}\text { Molecular } \\
\text { Formula }\end{array}$ & $\begin{array}{l}\text { Weight } \\
(\mathrm{g} / \mathrm{mol})\end{array}$ & $\begin{array}{l}\text { Hydrogen Bond } \\
\text { Donor }\end{array}$ & $\begin{array}{l}\text { Hydrogen Bond } \\
\text { Acceptor }\end{array}$ & $\begin{array}{l}\text { Topological Polar } \\
\text { Area }\left(\AA^{2}\right)\end{array}$ \\
\hline Beta-Eudesmol & $\mathrm{C}_{15} \mathrm{H}_{26} \mathrm{O}$ & 222.37 & 1 & 1 & 20.2 \\
\hline Elemol & $\mathrm{C}_{15} \mathrm{H}_{26} \mathrm{O}$ & 222.37 & 1 & 1 & 20.2 \\
\hline Verbenol & $\mathrm{C}_{10} \mathrm{H}_{16} \mathrm{O}$ & 152.23 & 1 & 1 & 20.2 \\
\hline Pinocarvone & $\mathrm{C}_{10} \mathrm{H}_{14} \mathrm{O}$ & 150.22 & 0 & 1 & 17.1 \\
\hline Myrtenal & $\mathrm{C}_{10} \mathrm{H}_{14} \mathrm{O}$ & 150.22 & 0 & 1 & 17.1 \\
\hline Myrtenol & C10H16O & 152.23 & 1 & 1 & 20.2 \\
\hline Trans- Carveol, & $\mathrm{C}_{10} \mathrm{H}_{16} \mathrm{O}$ & 152.23 & 1 & 1 & 20.2 \\
\hline $\begin{array}{l}\text { Trans- } \\
\text { Pinocarveol, }\end{array}$ & $\mathrm{C}_{10} \mathrm{H}_{16} \mathrm{O}$ & 152.23 & 1 & 1 & 20.2 \\
\hline Ligand & $\begin{array}{l}\text { Molecular } \\
\text { Formula }\end{array}$ & $\begin{array}{l}\text { Weight } \\
(\mathrm{g} / \mathrm{mol})\end{array}$ & $\begin{array}{l}\text { Hydrogen Bond } \\
\text { Donor }\end{array}$ & $\begin{array}{l}\text { Hydrogen Bond } \\
\text { Acceptor }\end{array}$ & $\begin{array}{l}\text { Topological Polar } \\
\text { Area }\left(\AA^{2}\right)\end{array}$ \\
\hline Beta-Eudesmol & $\mathrm{C}_{15} \mathrm{H}_{26} \mathrm{O}$ & 222.37 & 1 & 1 & 20.2 \\
\hline Elemol & $\mathrm{C}_{15} \mathrm{H}_{26} \mathrm{O}$ & 222.37 & 1 & 1 & 20.2 \\
\hline Verbenol & $\mathrm{C}_{10} \mathrm{H}_{16} \mathrm{O}$ & 152.23 & 1 & 1 & 20.2 \\
\hline Pinocarvone & $\mathrm{C}_{10} \mathrm{H}_{14} \mathrm{O}$ & 150.22 & 0 & 1 & 17.1 \\
\hline Myrtenal & $\mathrm{C}_{10} \mathrm{H}_{14} \mathrm{O}$ & 150.22 & 0 & 1 & 17.1 \\
\hline Myrtenol & $\mathrm{C} 10 \mathrm{H} 16 \mathrm{O}$ & 152.23 & 1 & 1 & 20.2 \\
\hline Trans- Carveol, & $\mathrm{C}_{10} \mathrm{H}_{16} \mathrm{O}$ & 152.23 & 1 & 1 & 20.2 \\
\hline $\begin{array}{l}\text { Trans- } \\
\text { Pinocarveol, }\end{array}$ & $\mathrm{C}_{10} \mathrm{H}_{16} \mathrm{O}$ & 152.23 & 1 & 1 & 20.2 \\
\hline
\end{tabular}


Nadjat et al. / Uluslararası Tarım Araştırmalarında Yenilikçi Yaklaşımlar Dergisi /

International Journal of Innovative Approaches in Agricultural Research, 2021, Vol. 5 (3), 269-278

Table 2. The interactions of Pistacia atlantica terpenoids molecules with the COVID 19 main protease.

\begin{tabular}{|c|c|c|c|c|c|}
\hline Ligand & $\begin{array}{l}\text { Docking } \\
\text { affinity } \\
\text { Kcal/mol) }\end{array}$ & $\begin{array}{l}\text { Distance } \\
\text { from rmsd } \\
\text { l.b. }\end{array}$ & $\begin{array}{l}\text { Best mode } \\
\text { rmsd u.b. }\end{array}$ & $\begin{array}{l}\text { Residues } \\
\text { Hydrogen bond } \\
\text { interaction }\end{array}$ & Distance $(\AA)$ \\
\hline Beta- & -5.5 & 0 & 0 & Ser 158 & 2.87 \\
\hline \multirow{2}{*}{ Eudesmol } & & & & Lys 102 & 2.98 \\
\hline & & & & Asp 153 & 2.94 \\
\hline Elemol & -5.2 & 0 & 0 & Ser 158 & 2.91 \\
\hline Verbenol & -5.2 & 0 & 0 & Thr 111 & 3.32 \\
\hline Pinocarvone & -5.1 & 0 & 0 & Trp207 & 3.09 \\
\hline Myrtenal & -4.9 & 0 & 0 & Thr 292 & 3.05 \\
\hline \multirow[t]{3}{*}{ Myrtenol } & -4.9 & 0 & $\overline{0}$ & Asn 151 & 2.92 \\
\hline & & & & Thr 111 & 2.92 \\
\hline & & & & Thr 111 & 3.04 \\
\hline Trans- Carveol & -4.9 & 0 & 0 & Lys 5 & 2.86 \\
\hline
\end{tabular}

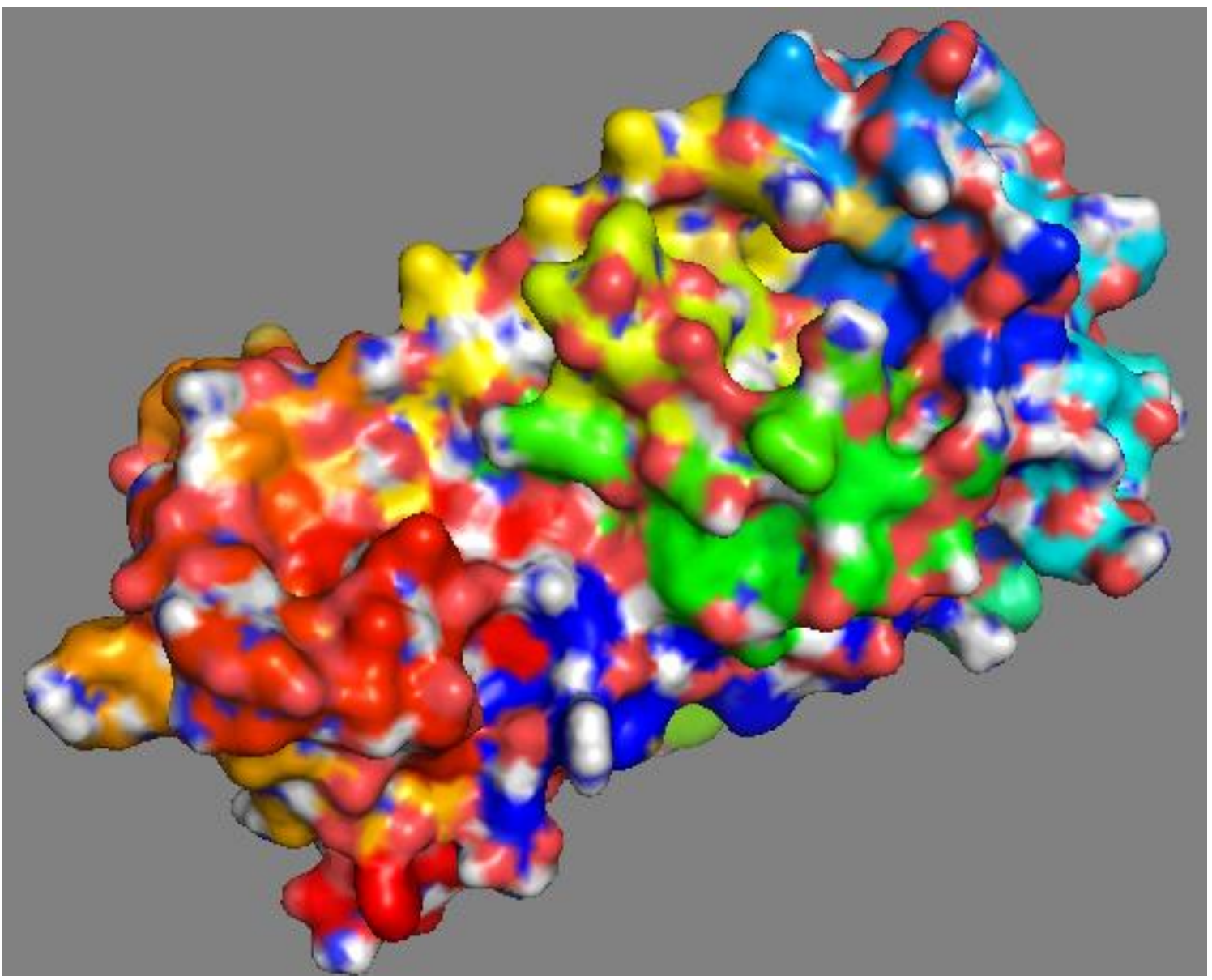

Figure 1. 3D structure of 2019-nCoV (https://www.rcsb.org/) 


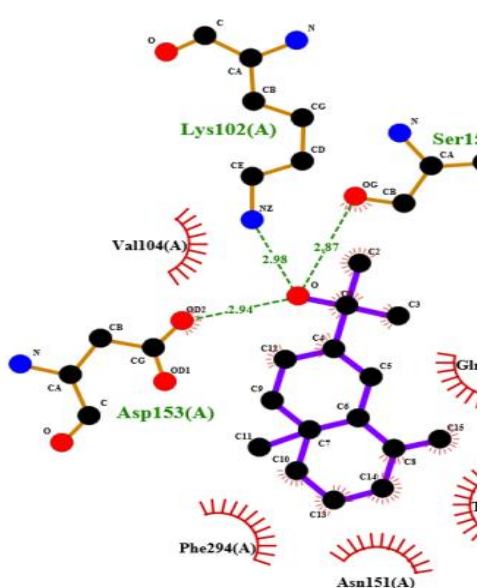

B-Eudesmol

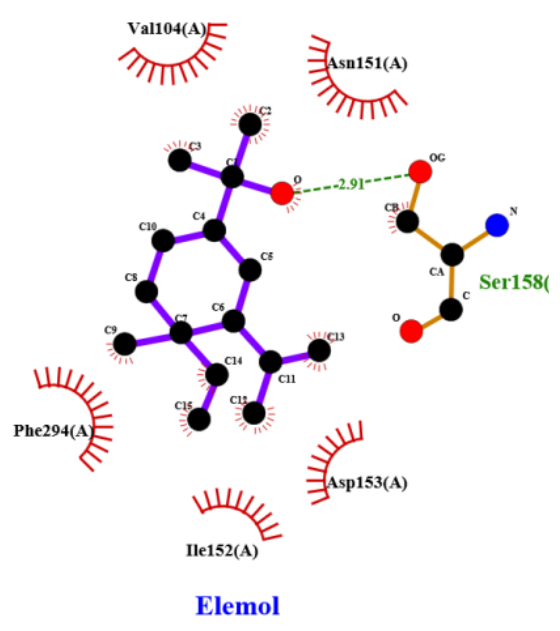

Elemol

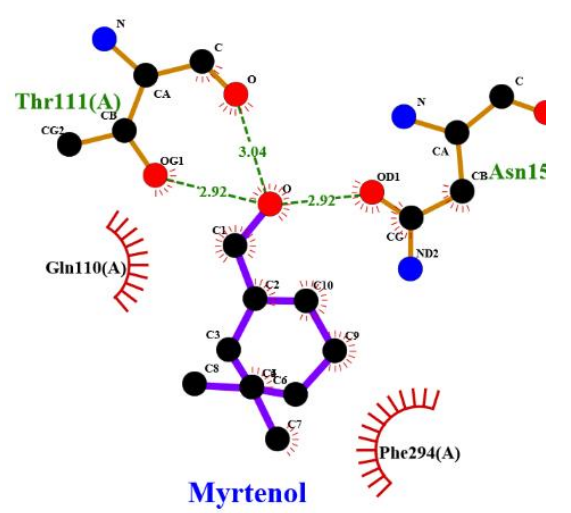

Myrtenol

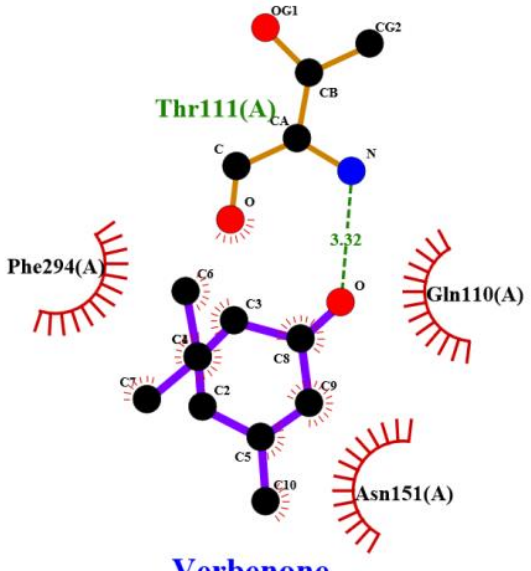

Verbenone

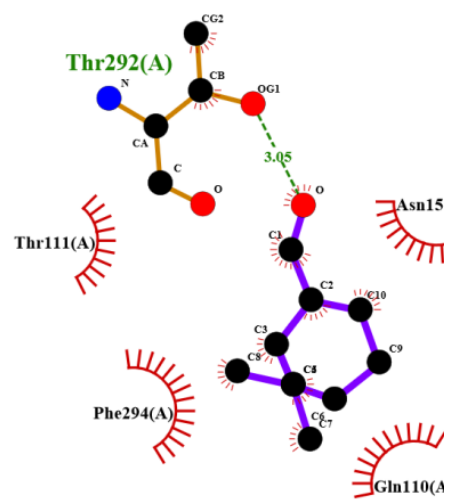

Myrtenal

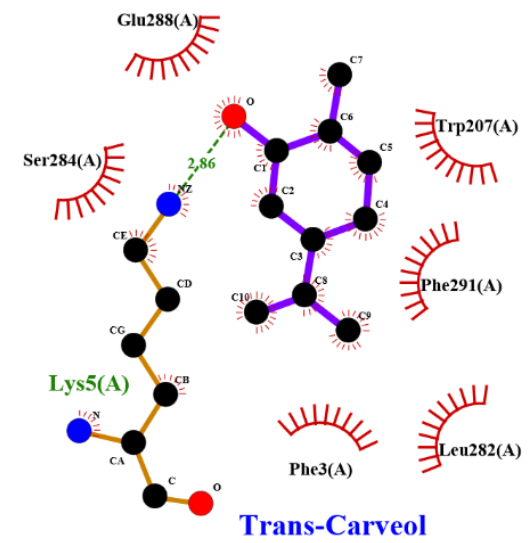

Figure 2. $2 \mathrm{D}$ View of the binding conformation of the ligands interaction with a target (2019-nCoV) main protease.

\section{Discussion}

In this study, twenty terpenoids components provided from $P$. atlantica Desf. were docked. seven compounds engendered highest energy and stable binding with SARS-CoV-2 main protease. These results can be explained by the presence of sesquiterpenes compounds in natural products generated an antiviral activity (Vieira et al., 2014). Generally, these compounds were associated with divers' biological activities.

According to Fatemeh et al. (2018), mono, di and triterpenoids are associated with antiinflammatory and antimicrobial effects. Also, hydroxy groups in terpenoids compounds play a signifying role in the interactions with the active site of SARS-CoV-2Mpro (Aziz et al., 2018).

The molecular weight of terpenoids of $P$. atlantica Desf. have low weight compared with isotymol $(220.31 \mathrm{~g} / \mathrm{mol})$ that has signaled by Abdelli et al. (2020), which has inhibitor effect against Coronavirus. Researches were oriented toward small compounds which formed the strong Hydrogen bonds (Pant et al.,2020). 
Nadjat et al. / Uluslararası Tarım Araştırmalarında Yenilikçi Yaklaşımlar Dergisi /

International Journal of Innovative Approaches in Agricultural Research, 2021, Vol. 5 (3), 269-278

The study results indicated that Beta-Eudesmol, Elemol, Verbenol, Pinocarvone, Myrtenal, Myrtenol and Trans-Carveol from P. atlantica Desf have a potential inhibition of SARS-CoV-2Mpro, which should be explored in further investigations.

\section{CONCLUSION}

In this research the inhibitory potential of the terpenoids compounds of $P$. atlantica have studied againstSARS-CoV-2 main protease using molecular docking approach. Natural products with antiviral potency have to pay attention for researchers. Nevertheless, no earlier reports have found the antiviral activity of $P$. atlantica, except Karimi et al (2020), Consequently, $P$. atlantica offers an alternative inhibitor source against this novel coronavirus.

\section{REFERENCES}

Aanouz, I., Belhassan, A., El-Khatabi, K., Lakhlifi, K., El-ldrissi, M., \& Bouachrine, M. 2020. Moroccan Medicinal plants as inhibitors against SARS-CoV-2 main protease: Computational investigations, Journal of Biomolecular Structure and Dynamics.

Abdelli, I., Hassani, F., Bekkel Brikci, S., \& Ghalem, S. 2020. In silico study the inhibition of Angiotensin converting enzyme 2 receptor of COVID-19 by Ammoides verticillata components harvested from western Algeria. Journal of Biomolecular Structure and Dynamics, (just-accepted), 1-17.

Ait Said, S., Fernandez, C., Greff, S., Derridj, A., Gauquelin, T., \& Mevy, J., 2011.Interpopulation variability of leaf morpho-anatomical and terpenoid patterns of Pistacia atlantica Desf. Ssp atlantica growng along an aridity gradient in Algeria. Flora-Morphology, Distribution, Functional Ecology of plants, 206(4), 397-405.

Anand, K., Ziebuhr, J., Wadhwani, P., Mesters, J. R., \& Hilgenfeld, R. 2003. (3CL pro) Structure: Basis for design of Anti-SARS drugs. Science, 300(5626), 1763-1767.

Astani, A., Reichling, J., \& Schnitzler, P. 2011. Screening for antiviral activities of isolated compounds from essential oils. Evidence-based complementary and alternative medicine.

Benhammou, A., Yaacoubi, A., Nibou, L., \& Tanouti, B. 2007. Chromium (VI) adsorption from aqueous solution onto Moroccan Al-pillared and cationic surfactant stevensite. Journal of hazardous materials, 140(1-2), 104-109.

Benhammou, N., Bekkara, F. A., \& Panovska, T. K. 2008. Antioxidant and antimicrobial activities of the Pistacia lentiscus and Pistacia atlantica extracts. African Journal of Pharmacy and Pharmacology, 2(2), 022-028.

Benhassaini, H., Benabderrahmane, M., \& Chikhi, K. 2003. Contribution à l'évaluation de l'activité antiseptique de l'oléorésine et des huiles essentielles du pistachier de l'Atlas sur certaines sources microbiennes: candida albicans (ATC 20027), candida albicans (ATCC 20032) et saccharomyces cerevisiae. Ethnopharmacologia, 30, 38-46.

Berman H, Westbrook J, Feng Z, Gilliland G, Bhat T, Weissig H, Shindyalov I, Bourne P. 2000. The protein data bank. 
Bobone, S.; Hilsch, M.; Storm, J.; Dunsing, V.; Herrmann, A.; Chiantia, S. 2017. Phosphatidylserine Lateral Organization Influences the Interaction of Influenza Virus Matrix Protein 1 with Lipid Membranes.

Boopathi, S., Poma, A. B., \& Kolandaivel, P. 2020. Novel 2019 Coronavirus Structure, Mechanism of Action, Antiviral drug promises and rule out against its treatment. Journal of Biomolecular Structure and Dynamics, (just-accepted), 1-14.

Chang K. O., Y. Kim, S. Lovell, A. D. Rathnayake, and W. C. Groutas,. 2019. “Antiviral drug discovery: Norovirus proteases and development of inhibitors," Viruses, vol. 11, no. 2, pp. 1-14.

Chen, Y.; Liu, Q.; Guo, D. 2020. Emerging coronaviruses: Genome structure, replication, and pathogenesis.J. Med.

Daget P, Godron. M,. 1974. Vocabulaire d'écologie, Paris, Hachette, 275p.

DeLano, W. L. 2002. Pymol: An open-source molecular graphics tool. CCP4 News. Protein Crystallography.

El Oualidi, J., Ater, M., \& Taleb, A. 2004. Conception, essai et évaluation de meilleures pratiques de conservation in situ d'espèces végétales sauvages d'importance économique. Rap. Nat. Proj. Rég. EP/INT0204/GEF.

Farhoosh, R., Tavakoli, J., \& Khodaparast, M. H. H. 2008. Chemical composition and oxidative stability of kernel oils from two current subspecies of Pistacia atlantica in Iran. Journal of the American Oil Chemists' Society, 85(8), 723.

Fatemeh Mahjoub1, Kambiz Akhavan Rezayat2, Mahdi Yousefi3, Masoud Mohebbi4, Roshanak Salari5., 2018. Pistacia atlantica Desf. A review of its traditional uses, phytochemicals and Pharmacology. Journal of Medicine and Life Vol. 11, Issue 3, July-September 2018, pp.180-186

Hamdan, I. I., \& Afifi, F. U. 2004. Studies on the in vitro and in vivo hypoglycemic activities of some medicinal plants used in treatment of diabetes in Jordanian traditional medicine. Journal of ethnopharmacology, 93(1), 117-121.

Höfer, C.T.; Di Lella, S.; Dahmani, I.; Jungnick, N.; Bordag, N.; Bobone, S.; Huang, Q.; Keller, S.; Herrmann, A.; Chiantia, S. 2019. Structural determinants of the interaction between influenza A virus matrix protein M1 and lipid membranes. Biochim. Biophys. Acta Biomembr. 1861, 1123-1134.

Jin, Z., Du, X., Xu, Y., Deng, Y., Liu, M., Zhao, Y., Yang, H. 2020. Structure-based drug design, virtual screening and high-throughput screening rapidly identify antiviral leads targeting COVID-19. BioRxiv, 2020.02.26.964882.

Jaghoori, M. M., Bleijlevens, B., \& Olabarriaga, S. D. 2016. 1001 ways to run AutoDock Vina for virtual screening. Journal of computer-aided molecular design, 30(3), 237-249.

Karimi Ali , Mohmmad Taghi Moradi , Asghar Gafourian. 2020. In Vitro Anti-adenovirus Activity and Antioxidant Potential of Pistacia atlantica Desf. Leaves._Research Journal of Pharmacognosy (RJP) 7(2): 53-60.

Konovalov, O., Myagkov, I., Struth, B., \& Lohner, K. 2002. Lipid discrimination in phospholipid monolayers by the antimicrobial frog skin peptide PGLa. A synchrotron X-ray grazing incidence and reflectivity study. European Biophysics Journal, 31(6), 428-437.

Laskowski, R. A., \& Swindells, M. B. 2011. LigPlot+: multiple ligand-protein interaction diagrams for drug discovery. 51 (10), 2778-2786. 
Liu, Y. W., Huang, C. F., Huang, K. B. and Lee, F. J. 2005. Role for Gcs1p in regulation of Arl1p at transGolgi compartments. Mol Biol Cell 16, 4024-33.

Mcconkey B, Sobolev V, Edelman M. 1983. The performance of current methods in ligand-protein docking. Curr Sci;83.

Medeiros, L.B.P.; Rocha, M.D.S.; Lima, S.G.D.; Júnior, G.R.D.S.; Citó, A.M.D.G.L.; Silva, D.D.; Lopes, J.A.D.; Moura, D.J.; Saffi, J.; Mobin, M.; et al. 2012. Chemical constituents and evaluation of cytotoxic and antifungal activity of Lantana camara essential oils. Rev Bras Farmacogn. 22, 12591267.

Monjauze, A. 1980. Connaissance du bétoum Pistacia atlantica Desf.

N. Aziz, M. Y. Kim, and J. Y. Cho. 2020. Anti-inflammatory effects of luteolin: A revie of in vitro, in vivo, and in silico studies, J. Ethnopharmacol., 225: 342-358.

Pant, S., Singh, M., Ravichandiran, V., Murty, U. S. N., \& Srivastava, H. K. 2020. Peptide-like and smallmolecule inhibitors against Covid-19. Journal of Biomolecular Structure and Dynamics, 1-15.

Pillaiyar, T., Manickam, M., Namasivayam, V., Hayashi, Y., \& Jung, S. H. 2016. An overview of severe acute respiratory syndrome-coronavirus (SARS-CoV) 3CL protease inhibitors: Peptidomimetics and small molecule chemotherapy. Journal of Medicinal Chemistry, 59(14), 6595-6628.

Quézel, P., \& Médail, F. 2003. Ecologie et biogéographie des forêts du bassin méditerranéen. Ecology and Biogeography of the forests of the Mediterranean basin.

Sandeep, G., Nagasree, K. P., Hanisha, M., \& Kumar, M. M. K. 2011. AUDocker LE: A GUI for virtual screening with AUTODOCK Vina. BMC research notes, 4(1), 1-4.

Sanner, M. F. 1999. Python: a programming language for software integration and development. J Mol Graph Model, 17(1), 57-61.

Subramanian Boopathi, Adolfo B. Poma \& Ponmalai Kolandaivel. 2020. Novel 2019 coronavirus structure, mechanism of action, antiviral drug promises and rule out against its treatment, Journal of Biomolecular Structure and Dynamics,

Suyash Pant, Meenakshi Singh, V. Ravichandiran, U. S. N. Murty \& Hemant Kumar Srivastava. 2020. Peptide-like and small-molecule inhibitors against Covid-19, Journal of Biomolecular Structure and Dynamics, DOI: 10.1080/07391102.2020.1757510.

Topçu, G., Ay, M., Bilici, A., Sarıürkcü, C., Öztürk, M., \& Ulubelen, A. 2007. A new flavone from antioxidant extracts of Pistacia terebinthus. Food Chemistry, 103(3), 816-822.

Trott, O., \& Olson, A. J. 2010. AutoDock Vina: Improving the speed and accuracy of docking with a new scoring function, efficient optimization, and multithreading. Journal of Computational Chemistry, 31(2), 455-461.

Vieira, P., Morais, S., Bezerra, F., et al. 2014. Chemical composition and antifungal activity of essential oils from Ocimum species. Ind Crop Prod 55:267-71.

X. Liu and X.-J. Wang. 2020. "Potential inhibitors against 2019-nCoV coronavirus M protease from clinically.

X. Xu, P. Chen, J. Wang, et al. 2020. Evolution of the novel coronavirus from the ongoing Wuhan outbreak and modeling of its spike protein for risk of human transmission, Sci. China Life Sci. 63 457e460 
Xue, X.; Yu, H.; Yang, H.; Xue, F.; Wu, Z.; Shen, W.; Li, J.; Zhou, Z.; Ding, Y.; Zhao, Q.; et al. 2008. Structures of two coronavirus main proteases: Implications for substrate binding and antiviral drug design. J. Virol., 82, 2515-2527.

Yang, H., Yang, M., Ding, Y., Liu, Y., Lou, Z., Zhou, Z., Sun, L., Mo, L., Ye, S., Pang, H., Gao, G. F., Anand, K., Bartlam, M., Hilgenfeld, R., \& Rao, Z. 2003. The crystal structures of severe acute respiratory syndrome virus main protease and its complex with an inhibitor. Proceedings of the National Academy of Sciences, 100(23), 13190-13195.

Zhao, Q., Li, S., Xue, F., Zou, Y., Chen, C., Bartlam, M., \& Rao, Z. 2008. Structure of the main protease from a Global Infectious Human Coronavirus, HCoV-HKU1. Journal of Virology, 82(17), 8647-8655. 